\title{
Impact of Climate Change on Sea Surface Temperature and Chlorophyll-a Concentration in South Sukabumi Waters
}

\author{
Mamat Suhermat ${ }^{1,2 *}$, Muhammad Dimyati², Supriatna², Martono ${ }^{1}$ \\ ${ }^{1}$ Center of Atmospheric Science and Technology (LAPAN), Bandung, Indonesia \\ 2Department of Geography, Faculty of Mathematics and Natural Sciences, Universitas Indonesia, Depok 16424 Indonesia
}

\begin{abstract}
Indonesia territorial waters are very vulnerable to the impacts of climate change. Research about the variations of sea surface temperature and chlorophyll-a concentration in the southern waters of Java has been undertaken by several researchers. However, the research is still in the scope of regional scale south of Java. This research was conducted to determine the impact of climate change on sea surface temperature and chlorophyll-a concentration in Sukabumi waters. The data used consisted of IOD index anomalies, sea surface temperature and monthly chlorophyll-a concentrations from December 2002 to November 2020. Descriptive analysis was used to determine seasonal and inter-annual variability and linear regression method was used to analyze trends in changes in sea surface temperature (SST) and chlorophyll-a concentration. The results showed that the seasonal variation was influenced by the monsoon, while the interannual variation was influenced by the Indian Ocean Dipole. Climate change causes SST and chlorophyll-a concentrations to increase. In the 2003-2020 time period, SPL increased by 0.08 ${ }^{\circ} \mathrm{C}$ and an increase in chlorophyll-a concentration by $0.03 \mathrm{mg} / \mathrm{m}^{3}$.
\end{abstract}

Keywords: climate change, SST, chlorophyll-a concentration, MODIS, IOD

\begin{abstract}
ABSTRAK
Perairan selatan Sukabumi yang berhadapan langsung dengan samudera Hindia sangat rentan terhadap dampak perubahan iklim. Penelitian mengenai variasi suhu permukaan laut dan konsentrasi klorofil-a di perairan selatan Jawa sudah dilakukan oleh beberapa peneliti sebelumnya. Namun penelitian tersebut masih dalam lingkup skala regional selatan Jawa. Penelitian ini dilakukan untuk mengetahui dampak perubahan iklim terhadap suhu permukaan laut dan konsentrasi klorofil-a di Perairan selatan Sukabumi. Data-data yang digunakan terdiri dari indeks IOD, suhu permukaan laut dan konsentrasi klorofil-a bulanan periode Desember 2002 hingga November 2020. Metode yang digunakan dalam penelitian ini adalah analisis deskripsi dan regresi linier. Hasil penelitian menunjukkan bahwa variasi musiman suhu permukaan laut dan konsentrasi klorofil-a di perairan ini dipengaruhi oleh monsun, sedangkan variasi antar tahunan dipengaruhi oleh Indian Ocean Dipole. Perubahan iklim menyebabkan suhu permukaan laut dan konsentrasi klorofil-a mengalami kenaikan. Dalam periode waktu 2003-2020 suhu permukaan laut mengalami kenaikan sebesar $0,08^{\circ} \mathrm{C}$ dan kenaikan konsentrasi klorofil-a sebesar $0,03 \mathrm{mg} / \mathrm{m}^{3}$.
\end{abstract}

Kata kunci: perubahan iklim, SPL, konsentrasi klorofil-a, MODIS, IOD

Citation: Suhermat, M., Dimyati, M., Supriatna, S., Martono, M. (2021). Impact of Climate Change on Sea Surface Temperature and Chlorophyll-a Concentration in South Sukabumi Waters. Jurnal Ilmu Lingkungan, 19(2), 393-398, doi:10.14710/jil.19.2..393-398

\section{Introduction}

The increase of greenhouse gases emitted into the atmosphere are drive the global warming which cause climate change. The greenhouse gases in the atmosphere including carbon dioxide (CO2), methane (CH4), nitrogen oxides (N2O), sulphur hexafluoride (SF6), perfluorocarbons (PFCs) and hydrofluorocarbons (HFCs). Indonesia as an archipelago country in the tropics is very vulnerable to the impacts of climate change. The negative impacts of climate change in Indonesia including changes in rainfall patterns, seasonal shift, rising temperatures, sea level rise, increasing hydrometeorological disasters and biodiversity loss (Susandi, 2006; Measey, 2010).

One of the impacts of climate change on the marine sector is the shift of fish resources from tropical areas (low latitudes) to sub-tropical areas (IPCC, 2014; Syahailatua, 2008). The stock of marine fishery resources in the tropics has decreased. The southern region of Java, which is part of the management of marine and fisheries resources in WPPNRI 573, has a decrease in productivity, the farther fishground and fish shrink size (Jayawiguna et al., 2019).

The dynamics of the waters of Sukabumi which is the southern part of Java waters are influenced by

*Penulis korepondensi: msuhermat@gmail.com 
south java coastal current and south equatorial current (Wyrtki, 1962). In addition, the dynamics of these waters are also influenced by the Indian Ocean Dipole (IOD) phenomenon. IOD is a phenomenon of oceanatmosphere interaction that occurs in the tropical Indian Ocean. Beside the impact on changes in marine environmental conditions, IOD phenomenon also affects the dynamics of the atmosphere of the surrounding environment.

Research about the variations of sea surface temperature and chlorophyll-a concentration in the southern waters of Java has been undertaken by several researchers (Currie et al, 2013; Gaol et al, 2015). However, the research is still in the scope of regional scale south of Java with low spatial resolution. Moreover, previous studies have not included climate change factors.

Changes in sea surface temperature and chlorophyll-a concentrations significantly disrupt the productivity of marine resources. The impact of climate change has caused changes in the environmental conditions of the southern water of Java (Martono etal., 2020). The southern waters of Sukabumi, which are part of the east pole of IOD, are very important to study. The impact of climate change causes frequency increase of IOD events

Therefore, it is important to conduct research related to the impact of climate change. The purpose of this study was to determine the impact of climate change on sea surface temperature and chlorophyll-a concentrations in south Sukabumi waters.

\section{Method}

\subsection{Study Area}

The study location was Sukabumi waters, West Java located at $105^{\circ} 48^{\prime} 0^{\prime \prime}-107^{\circ} 4^{\prime} 0^{\prime \prime}$ BT dan $6^{\circ} 48^{\prime} 0^{\prime \prime}$ - 8० 48' 0" LS as shown in Figure 1.

\subsection{Data Collection}

The data used consists of monthly sea surface temperature, monthly chlorophyll-a concentration, and IOD index. The monthly sea surface temperature and chlorophyll-a concentration data from 2003-2020 were level 3 fields provided by the NASA Ocean Color (http://oceancolor.gsfc.nasa.gov). The level 3 productwas collected in TIF format with $4 \times 4 \mathrm{~km}$ image resolution. IOD Climate variability index data used DMI (Dipole Mode Index) from the Japan Agency for MarineEarth Science and Technology (http://www.jamstec.go.jp).

\subsection{Data Analysis}

The method used in this research is descriptive analysis and linear regression analysis. Descriptive analysis is used for analysis of seasonal patterns and variability. Meanwhile, linear regression was used to analyze the trend of changes in sea surface temperature (SST) and chlorophyll-a concentration.

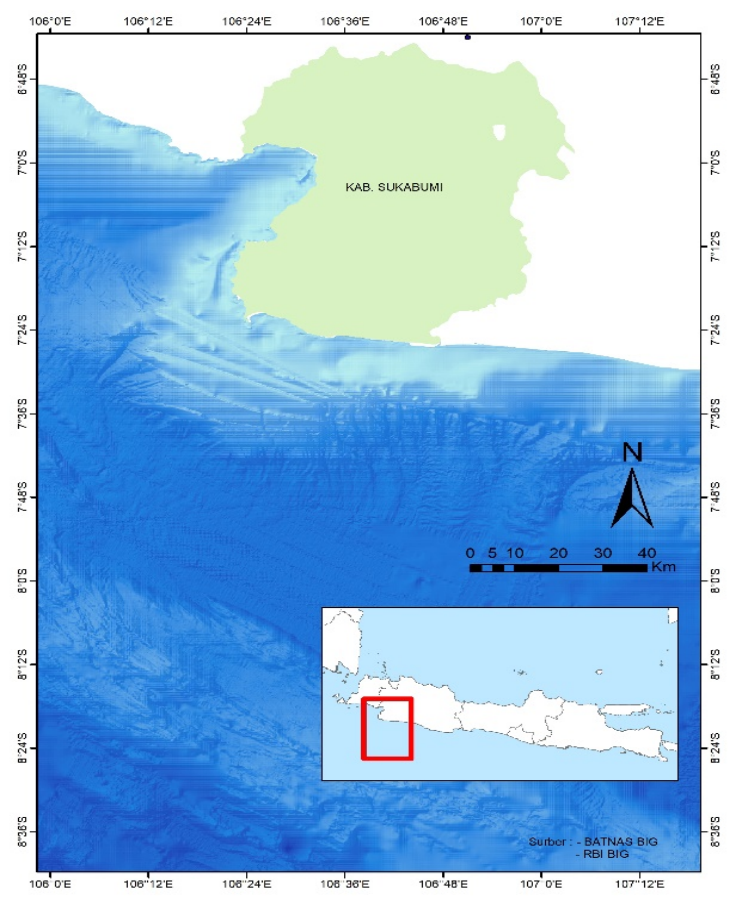

Figure 1 Research location on Sukabumi waters 
This study also analyzed the impact of IOD events on sea surface temperature and chlorophyll-a concentration. Monthly sea surface temperature and chlorophyll-a concentration data were converted into climatological averages. Furthermore, the average seasonal representing the western season (December to February), the first transitional season (March-May), east monsoon (June to August), the second transitional season (September-November) and annual anomalies were calculated. Annual anomaly data is used to determine the trend rate and impact of IOD on in sea surface temperature and chlorophyll-a concentrations changes.

\section{Result and Discussion}

The seasonal variation of SST and chlorophyll-a concentration in Sukabumi waters is shown in Figure 3. SST during the west season (December-February) and the first transitional season (March-May) was warm with an averaged $29.44{ }^{\circ} \mathrm{C}$, then decreases drastically during the east season (June-August) and the second transitional season (September-November) with the lowest average value $27.18{ }^{\circ} \mathrm{C}$. The concentration of chlorophyll-a during the west season and the first transition season was low about 0.2 $\mathrm{mg} / \mathrm{m}^{3}$, then increases when entering the east season and the second transitional season with the highest average value $0.78 \mathrm{mg} / \mathrm{m}^{3}$.

Figure 3 shows the seasonal pattern of SST in Sukabumi waters. In the west season and the first transitional season, the distribution of SST is relatively homogeneous with values about $29^{\circ} \mathrm{C}$. In the east season and the second transitional season, the distribution of SST varies between $26-28^{\circ} \mathrm{C}$. In the east season and the second transitional season, the coastal areas are relatively cooler than offshore area.

The seasonal pattern of chlorophyll-a concentration in Sukabumi waters is shown in Figure 4. The concentration of chlorophyll-a during the west season and the first transitional season in coastal areas is higher than offshore. In the eastern season and the second transitional season, the concentration of chlorophyll-a has increased significantly and spread over almost all water areas.

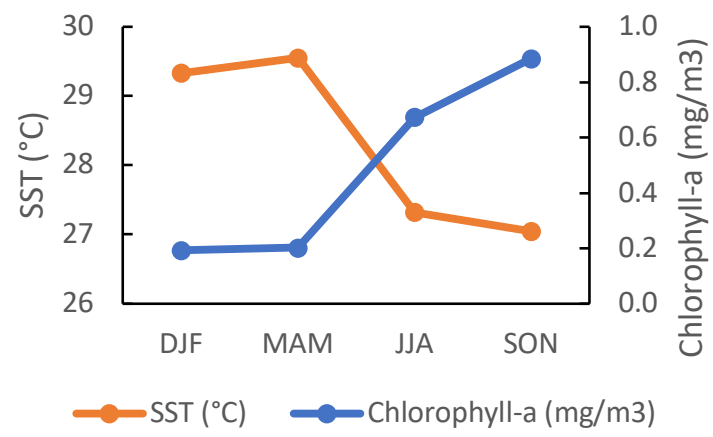

Figure 2 Seasonal variations of SST and Chlorophyll-a in Sukabumi waters.

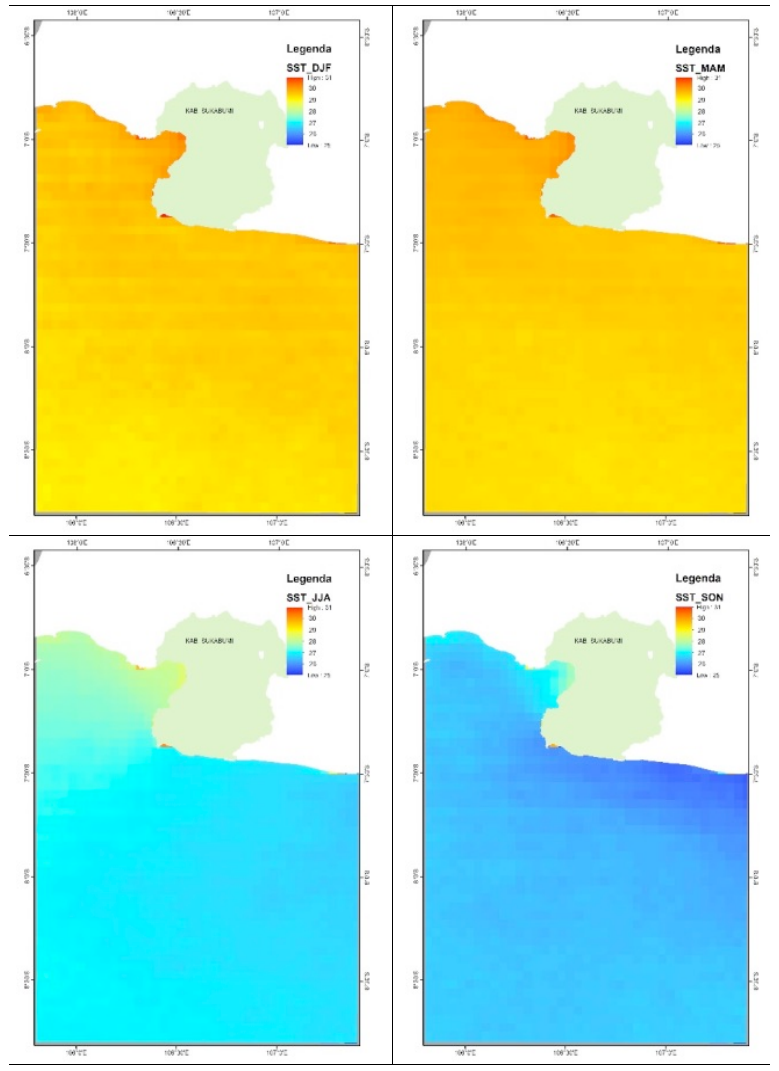

Figure 3 Seasonal pattern of SST in Sukabumi waters

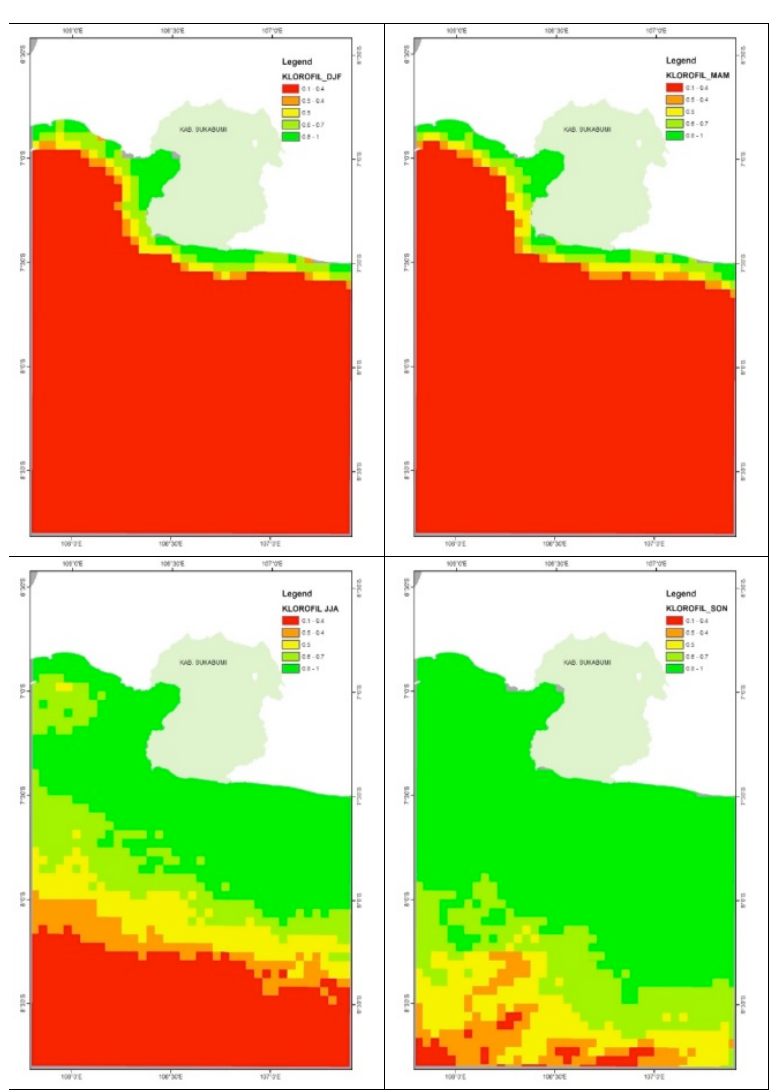

Figure 4 Seasonal patterns of chlorophyll-a concentrations in Sukabumi waters 


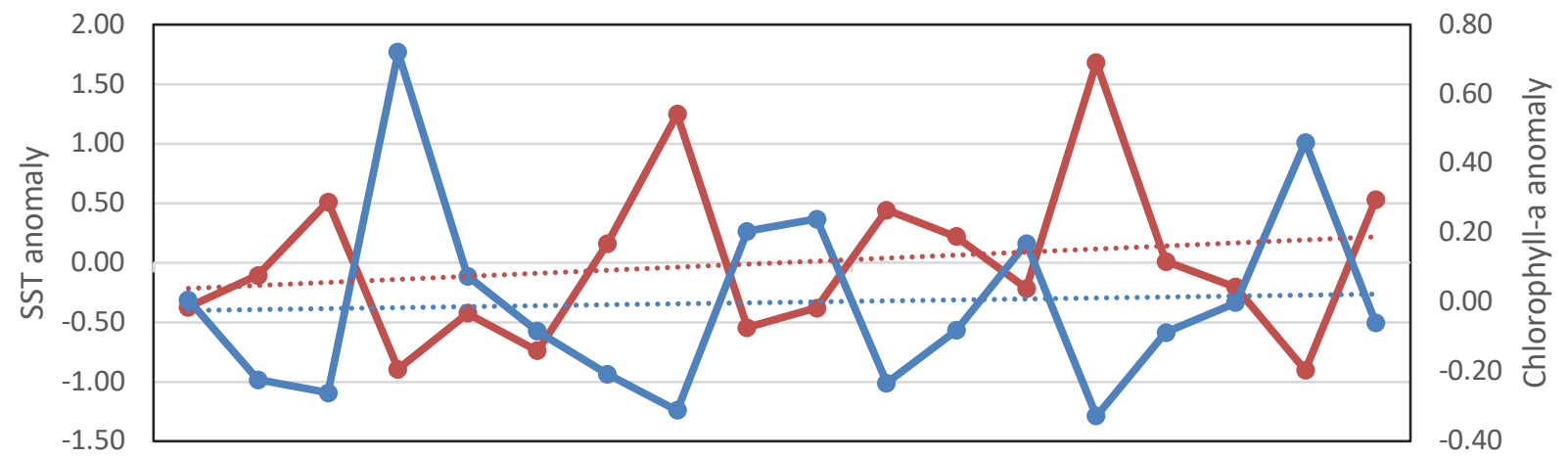

200320042005200620072008200920102011201220132014201520162017201820192020
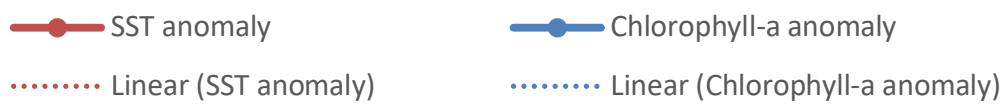

Figure 5 Inter-annual variation of SST anomaly and Chlorophyll-a anomaly in Sukabumi waters

The seasonal pattern of chlorophyll-a concentrations in Sukabumi waters shows that the chlorophyll-a concentration increases in the east season and the second transitional season with an average value $0.89 \mathrm{mg} / \mathrm{m}^{3}$, while the lowest average value occurs in the western season with an average value $0.20 \mathrm{mg} / \mathrm{m}^{3}$. The results of this study also indicate that chlorophyll-a concentrations tend to increase in coastal areas.

The inter-annual variation of SST anomaly and chlorophyll-a concentration in Sukabumi waters fluctuated as shown in Figure 5. A significant increase in SST occurred in 2010 which reached $1.25^{\circ} \mathrm{C}$ and 2016 reached $1.68{ }^{\circ} \mathrm{C}$, while a significant decrease occurred in 2006 about $-0.9{ }^{\circ} \mathrm{C}$. Meanwhile, a significant increase in chlorophyll-a occurred in 2006 reaching $0.72 \mathrm{mg} / \mathrm{m}^{3}$ and a decrease occurred in 2010 reaching $-0.31 \mathrm{mg} / \mathrm{m}^{3}$ and 2016 reaching $-0.33 \mathrm{mg} / \mathrm{m}^{3}$. This significant change was indicated as a result of the influence of IOD events.

Figure 6 (a) shows the pattern of SST anomalies in Sukabumi waters in the 2003-2020. In general, SST in the southern waters of Sukabumi has increased. The increase in SST in coastal waters tends to be stronger than in offshore waters. The highest increase in SST occurred in Palabuhanratu Bay which reached $1.2^{\circ} \mathrm{C}$. Figure 6 (b) shows the anomaly pattern of chlorophylla concentrations in Sukabumi waters in 2003-2020. The anomaly average of chlorophyll-a concentrations around the coast is higher than in other areas.

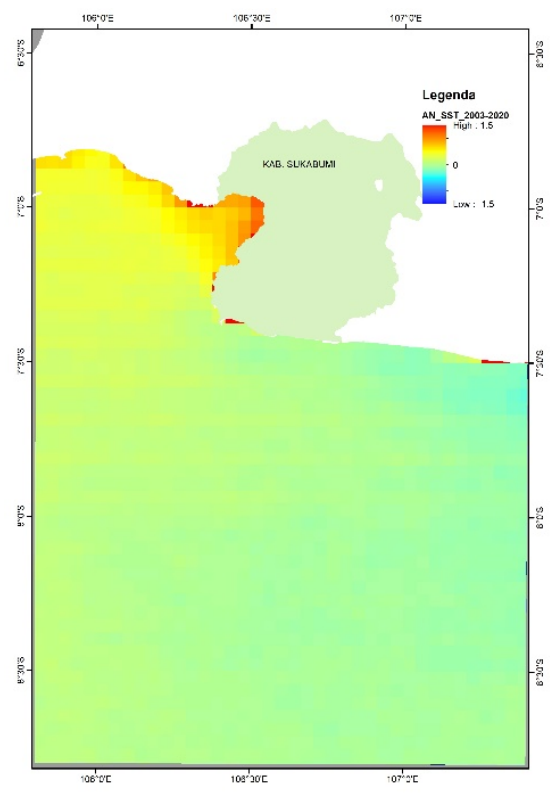

(a)

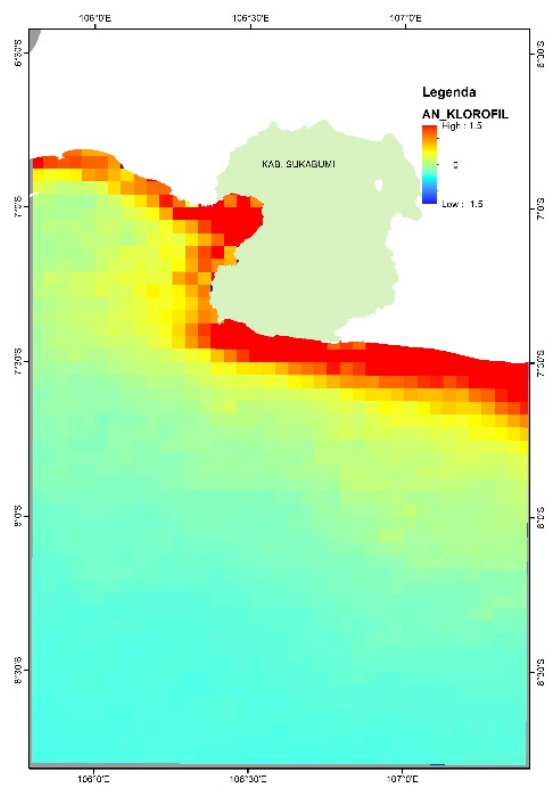

(b)

Figure 6 (a) SST anomaly pattern in Sukabumi waters (b) Chlorophyll-a anomaly pattern in Sukabumi waters 
The results of this study show the variability of seasonal and interannual in SST and chlorophyll-a concentrations. The spatial and temporal variations of SST and chlorophyll-a concentration in Indonesian waters are influenced by monsoon winds and climate phenomena such as the Indian Ocean Dipole and El Niño (Natalia, 2015). Seasonally, the highest average SST $29.55^{\circ} \mathrm{C}$ occurs in the first transitional season, while the lowest average $27.05^{\circ} \mathrm{C}$ occurs in the second transitional season. The results of this study are similar with the results of research conducted by Martono (2016) which states that SST in the southern waters of Java (including Sukabumi waters) increases in the western season and the first transitional season, while the lowest SST occurs in the second transitional season.

During west season, SST increase because the sun's position in the southern hemisphere results in high solar radiation in southern water of Sukabumi. During the rainy season the chlorophyll-a concentration in the coastal area is higher due to increased nutrient elements from river run-off. The increase in nutrient elements in coastal areas will be followed by an increase in chlorophyll-a concentrations.

In the east season and the second transitional season SST has decreased and the chlorophyll-a concentration has increased in all waters. This is similar with research conducted by Habibi (2012) which states that chlorophyll-a concentrations begin to increase in the east season and decrease in the west season. This significant change is caused by the upwelling process in southern Java which occurs between the eastern season and the second transitional season (Wyrtki, 1962; Qu et al, 2005; Kunarso et al, 2011). Upwelling is the process of increasing the mass of water from the bottom layer to the surface layer (Bowden, 1983). This increased water mass has cold temperatures, high salinity and rich in nutrient elements (Surinati, 2009). The upwelling process in the southern waters of Java is closely related to the southeast monsoon (Susanto and Marra, 2005).

In 2016 SST increased significantly and chlorophyll-a concentration decreased significantly. This condition is caused by IOD events. In 2016, a negative phase of IOD occurred as shown in Figure 8. The IOD index from May to November showed a fairly high decline reaching more than $-1^{\circ} \mathrm{C}$. The same result is shown by Yoga et al. (2014) that at the time of negative phase IOD, SST in southern Java increased and colorophyll-a decreased.

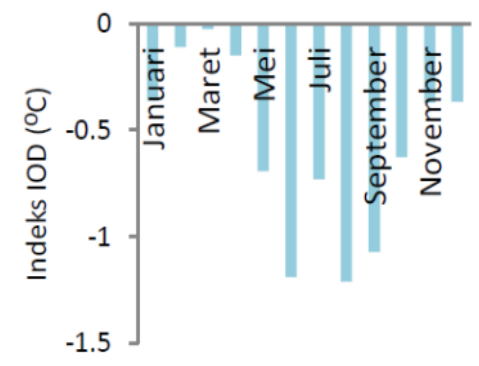

Figure 82016 monthly IOD index

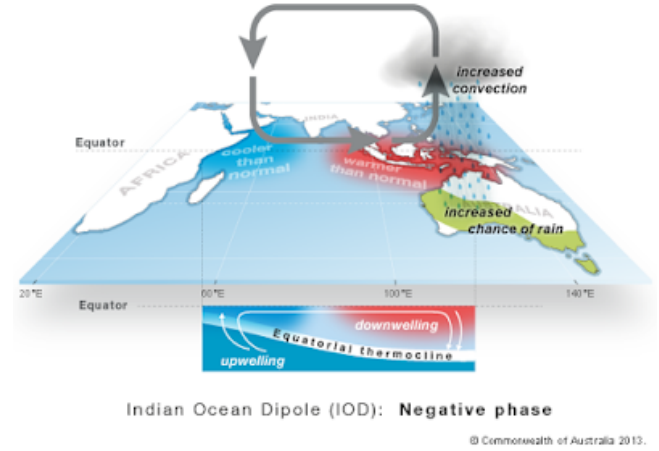

Figure 9 Negative Phase IOD (https://www.climate4life.info)

The mechanism of the 2016 negative phase IOD is shown in Figure 9. There has been a strengthening of the intensity of surface winds moving from the western Indian Ocean to Indonesia territory. This condition causes the warm water masses are also moving to Indonesia territory, so the surface temperatures in south Java sea is warmer than normal conditions. Due to intensive input of water masses from the western Indian Ocean, there is a buildup of water mass and thermocline layer decrease. This causes upwelling does not occur, the reverse process downwelling occurs. This mechanism caused during the negative phase of 2016 IOD there was chlorophyll-a concentration decrease in south Sukabumi waters.

\section{Conclusion}

Based on the analysis of the results, it can be concluded that the seasonal and inter-annual variations in SST and chlorophyll-a concentration in Sukabumi waters are influenced by monsoons and IOD. In the negative phase IOD, SST increased and chlorophyll-a concentration decreased. Climate change has an impact on SST and chlorophyll-a concentrations. In the 2003-2020 period, SST in these waters increased by $0.08{ }^{\circ} \mathrm{C}$ and chlorophyll-a concentrations increased by $0.03 \mathrm{mg} / \mathrm{m} 3$.

\section{Acknowledgement}

The authors thank to Indonesian Insitute of Sciences (LIPI), which has supported and funded degree by research program. This research also supported by Center of Atmospheric Science and Technology, National Institute of Aeronautics and Space.

\section{REFERENCES}

Bowden, K.F., (1983), Physical Oceanography of Coastal Waters. West Sussex: Ellis Horwood Limited, Publishers Chichester.

Currie, J.C., M. Lengaigne, J. Vialard, D.M. Kaplan, O. Aumont, S.W.A. Naqvi, and O. Maury, (2013), Indian Ocean Dipole and El Niño/Southern Oscillation impacts on 
regional chlorophyll anomalies in the Indian Ocean, Biogeosciences, 10, 6677-6698.

Gaol, J.L., R.R. Leben, S. Vignudelli, K. Mahapatra, Y. Okada, B. Nababan, M. Mei-Ling, K. Amri, R.E. Arhatinand M. Syahdan, (2015), Variability of satellite-derived sea surface height anomaly, and its relationship with Bigeye tuna (Thunnus obesus) catch in the Eastern Indian Ocean, European Journal of Remote Sensing, 48, 465-477.

Habibi, A. dan Setiawan, R. Y., (2010), Wind-driven Coastal Upwelling Along South of Sulawesi Island, Jurnal Ilmu Kelautan, 15 (20), 113-118.

IPCC (2014): Summary for policymakers. In: Climate Change 2014: Impacts, Adaptation, and Vulnerability. Part A: Global and Sectoral Aspects. Contribution of Working Group II to the Fifth Assessment Report of the Intergovernmental Panel on Climate Change [Field, C.B., V.R. Barros, D.J. Dokken, K.J. Mach, M.D. Mastrandrea, T.E. Bilir, M. Chatterjee, K.L. Ebi, Y.O. Estrada, R.C. Genova, B. Girma, E.S. Kissel, A.N. Levy, S. MacCracken, P.R. Mastrandrea, and L.L. White (eds.)]. Cambridge University Press, Cambridge, United Kingdom and New York, NY, USA, pp. 1-32.

Kunarso, S., Hadi, S., Ningsih, N.S., and Baskoro, M.S., (2011), Variabilitas Suhu dan Klorofil-a di Daerah Upwelling pada Variasi Kejadian ENSO dan IOD di Perairan Selatan Jawa sampai Timor, Ilmu Kelautan, 16 (3), 171180.

Martono, (2016), Seasonal and Interannual Variations of Sea Surface Temperature in the Indonesian Waters. Jurnal Forum Geografi, 30 (2), 120-129.

Martono, Susanti, I., Siswanto, B., Nurlatifah, A., Suhermat, M. dan Maryadi, E., (2020), Trends of significant wave height and sea level in the southern water of the Special Region of Yogyakarta. E3S Web of Conferences, 200, 02025.

Measey, M. (2010). Indonesia: A Vulnerable Country in the Face of Climate Change. Global Majority E-Journal, 1(1), $31-45$

Natalia, E. H., Kunarso, Rifai, A. (2015). Variabilitas Suhu Permukaan Laut dan Klorofil-A Kaitannya Dengan El Nino Southern Oscillation (ENSO) dan Indian Ocean Dipole (IOD) Pada Periode Upwelling 2010-2014 di Lautan Hindia (Perairan Cilacap). Oseanografi, 4(4), 661-669.

Qu, T., Du, Y., Strachan, J., Meyers, G., and Slingo, J., (2005), Sea Surface Temperature And Its Variability In The Indonesian Region, Oceanography, 18 (4), 50-61.

Surinati, D. (2009), Upwelling dan Efeknya terhadap Perairan Laut, Oseana, 36 (4), 35-42.

Susandi, A., (2006) Bencana Perubahan Iklim Global dan proyeksi Perubahan Iklim Indonesia, Kelompok Keahlian Sains Atmosfer, ITB.

Susanto, D., Gordon, A.L., and Zheng, Q., (2001) Upwelling along the coast of Java-Sumatra and Its Relation to ENSO, Geophysical Research Letter, 28 (8), 1599-1602.

Syahailatua, A., (2008), Dampak Perubahan Iklim Terhadap Perikanan, Oseana, 2, 25-32.

Wyrtki, K., (1962), The Upwelling in the Region between Java and Australia during the Southeast Monsoon, Aust. J. Mar. Freshw. Res, 13 (3), 217-225.

Yoga, R.B.B., Setyono, H., and Harsono, G., (2014), Dinamika Upwelling dan Downwelling Berdasarkan Variabilitas Suhu Permukaan Laut dan Klorofil-A di Perairan Selatan Jawa, Jurnal Oseanografi, 3(1), 57-66. 